\title{
ZNF292 wt Allele
}

National Cancer Institute

\section{Source}

National Cancer Institute. ZNF292 wt Allele. NCI Thesaurus. Code C142227.

Human ZNF292 wild-type allele is located in the vicinity of 6q14.3 and is approximately $111 \mathrm{~kb}$ in length. This allele, which encodes zinc finger protein 292 , is involved in transcriptional regulation. Mutations in the gene may be associated with gastric cancer, colorectal cancer and chronic lymphocytic leukemia. 